\section{FRAMING ATTICA: NEWSPRINT MEDIA CONSTRUCTION OF THE 1971 ATTICA PRISON RIOT: CLAIMS-MAKERS, FRAME SALIENCE AND THE CULTURAL GEOGRAPHY OF READERSHIP*}

\author{
ENMARCANDO ATTICA: CONSTRUCCIÓN MEDIÁTICA \\ DE LA PRENSA ACERCA DE LA REBELIÓN EN LA \\ PRISIÓN DE ATTICA: LOS RECLAMANTES, LA \\ PROMINENCIA DEL MARCO Y LA GEOGRAFÍA \\ CULTURAL DE LOS LECTORES
}

ENQUADRAMENTO DA ÁTICA: CONSTRUÇÃO DE MÍDIA DA IMPRENSA SOBRE A REBELIÃO NA PRISÃO DE ATTICA: RECLAMANTES, A PROEMINÊNCIA DO QUADRO E A GEOGRAFIA CULTURAL DOS LEITORES \title{
.
}

John P. Walsh, Ph.D. ${ }^{\text {a }}$ walshj@gvsu.edu Joanne Ziembo-Vogl, , Ph.D. ${ }^{\text {b }}$ ziembovj@gvsu.edu

Jacquelynn Martin Ph.D. ${ }^{\mathrm{C}}$ martinjd@gvsu.edu Fecha de recepción: 1 de diciembre de 2015 Fecha de revisión: 28 de marzo de 2016 Fecha de aceptación: 2 de abril 2016

\begin{abstract}
Using frame analysis, the authors examine how historical narratives of the 1971 Attica Prison riot were driven in part by frame diversity and salience across differing cultural geographies. Comparison of constructed meaning in news articles published by the New York Times, the Chicago Tribune, and the Chicago Defender is presented. Viewpoints regarding the prison riot are linked to claims-makers sourced by the differing news outlets and contextual differences in portrayal are discussed with regard to the media's role in socially constructing perceptions of the Attica riot. Included is discussion regarding public policy agenda setting, triggering events, and the capacity of news media to shape local ways of knowing. Methodological considerations are presented linking media analysis, claims-making research, and cultura criminology theory to current forms of media presentation and future qualitative approaches to media analysis.
\end{abstract}

\footnotetext{
* Article of scientific investigation that shows the result of a finished investigation project about the media construction of the 1971 Attica, New York, U.S.A. prison riot. Investigation conducted at Grand Valley State University, Grand Rapids, Michigan, U.S.A..

a. School of Criminal Justice, Grand Valley State University, USA

b. School of Criminal Justice, Grand Valley State University, USA

c. School of Criminal Justice, Grand Valley State University, USA

NOTE A poster version of this study, The 1971 Attica Prison Uprising in Mainstream and Alternative Newsprint, was presented at the annual meeting of the Academy of Criminal Justice Sciences in Toronto, Canada in March, 2011. A preliminary version, The Construction and Representation of Social Order in the Prison Environment, was presented at the Midwest Criminal Justice Association annual meeting in Chicago, USA in September, 2011 and a concluding version, Media Construction of the 1971 Attica Prison Riot: Claims-Makers Frame Salience, and the Cultural Geography of Readership, was presented at the annual meeting of the American Society of Criminology in Chicago, USA in November, 2012. The authors wish to thank Maximo Anguiano for his assistance with data-entry.
}

MISIÓN JURÍDICA

Revista de Derecho y Ciencias Sociales Bogotá, D.C. (Colombia)

Colaboradores Externos Internacionales

Núm. 11 Año 2016

Julio - Diciembre, pp. 29-48

ISSN 1794-600X 


\section{KEYWORDS}

Attica Prison Riot, News Media, Frame Analysis, Salience, Constructed Meaning, Claimsmakers, Cultural Criminology

\section{RESUMEN}

Usando análisis de marco, los autores examinan cómo las narrativas históricas del motín en la prisión de Attica de 1971 fueron impulsadas en parte por la diversidad y prominencia de marco entre geografías culturales discrepantes. Se compara la construcción de sentido en artículos periodísticos publicados por New York Times, Chicago Tribune y Chicago Defender. Los puntos de vista acerca de la rebelión en la prisión vinculados a reclamantes cuya fuente eran las diferentes vertientes mediáticas y las diferencias contextuales de interpretación son discutidos con respecto al papel de los medios en la construcción social de la percepción del motín de Attica. Está incluido el debate sobre el establecimiento de la agenda de políticas públicas, los eventos disparadores y la capacidad de los medios de noticias para moldear las formas de conocimiento locales. Son expuestas consideraciones metodológicas que vinculan el análisis mediático, las investigaciones en efectuar reclamos y la teoría de criminología cultural con modos actuales de presentaciones mediáticas y futuras aproximaciones cualitativas al análisis de los medios.

\section{PALABRAS CLAVE}

Rebelión en la prisión de Attica, medios de comunicación, análisis de marco, prominencia, construcción de sentido, reclamantes, criminología cultural.

\section{RESUMO}

Usando quadro de análise, os autores examinam como as narrativas históricas do motim na prisão de Attica em 1971 foram impulsionadas, em parte, pela estrutura, diversidade e destaque entre diferentes geografias culturais. A construção de sentido é comparada em artigos de jornal publicados pelo New York Times, Chicago Tribune e Chicago Defender. Os pontos de vista sobre a rebelião no presídio ligada aos requerentes cuja fonte foi os diferentes aspectos da mídia e diferenças contextuais de interpretação são discutidas em relação ao papel da mídia na construção social da percepção do motim de Attica.
Está incluído o debate sobre a criação da agenda de políticas públicas, os disparadores de eventos e a capacidade dos meios de comunicação para moldar as formas de conhecimento local. São expostas considerações metodológicas ligando análise de mídia, pesquisa em reivindicações e teoria da criminologia cultural com os modos atuais de mídia e futuras abordagens qualitativas para a análise de mídia

\section{PALAVRAS-CHAVE}

Rebelião na prisão de Attica, mídia, quadro de análise, destaque, construção de significado, reclamantes, criminologia cultural.

\section{INTRODUCTION}

Attica. One of those singular words in American history that in September, 1971 and still today overflows with a ripeness of meaning unmatched by any other prison riot before or after. But reflective of what and who's meaning? A racist meaning exemplified by the warden's comment that the prison riot was led by "coloured ${ }^{1}$ Communist Maoist inmates" (Apple, 2006: 62)? Calls for prison reform by liberals outraged by the conservative 'doctrine of crushing power' used to quell prison rioting (Garson, 1972: 411)? Do politics combine with the view of an open versus closed organizational system as suggested by Stojkovic, Kalinich, and Klofas who comment that Attica, like earlier prison riots, 'cannot be understood without reference to conservative criminal justice polices and the resulting overcrowding of prisons' (2008: 8)? Or, is the reflected meaning that of a closed organizational system permeated and made open by a new and more vocal class of inmate, an inmate bringing to the prison setting the social problems inherent in American society (Mahan and Lawrence, 1996, Williams, 1997, Starr, 1973, Benjamin and Rapport, 1974)? Regardless of the answer, many cite Attica as the deadliest, bloodiest prison uprising in the history of the United States (Time, 1972, Mahan, 1994, Mahan and Lawrence, 1996) and a symbol of this turbulent era in American history (Columbia Journalism Review, 1971: 2). With hindsight, much has been written, then and now, of the meaning of Attica (Wicker, 1975; New York State Special

1. Words such as "coloured" and "negro" are unedited quotes and reflective of the racist views existing at this time in American history. 
Commission on Attica, 1972; Roberts, 2011; Useem and Kimball, 1989, Carrabine, 2005, Thompson, 2011). The focus of this study is to determine how the Attica Prison riot was portrayed in the newsprint media of the day - what meaning was being proffered to inform and influence the American public? The New York Times, the Chicago Tribune, and the Chicago Defender are examined to determine the forces and claims-makers driving the narrative of Attica across differing readership and cultural geographies.

\section{LITERATURE REVIEW}

\subsection{The Attica Prison Riot - Spectacle, Revolution, and Race}

September 9, 1971 marked the beginning of the Attica Prison riot - a riot characterized as one of the 'bloodiest and most violent riots in American prison history' (Mahan, 1994: 253; Time, Inc., 1972). Four days and 43 dead bodies later, Attica had become 'the most famous prison in the world,' and the focal point in American corrections history that would eventually usher in the community model of corrections (Useem and Kimball, 1989: 18). In the aftermath of the Attica slaughter (The Nation, 1971), community members, the media, government officials, and politicians - from local congressional representatives to Governor Nelson Rockefeller and President Richard Nixon - presented their perspectives (sometimes denials) on the causal factors that prompted Attica to reach its boiling point and erupt in violence.

Attica Prison is located in rural upstate (Attica) New York. In 1971 Attica was the area's primary employer and the majority of its white prison guards lived in the middle-class Attica community. In stark contrast, the population of Attica inmates was increasing growing 'younger and more nonwhite...54\% were black, 37\% were white, and 9\% were Hispanic' (Useem and Kimball, 1989: 22). Harring and Dowdall describe the impact of race coupled with 70 s-era politicization:

The uprising at Attica Prison in 1971 represented an era of increasing politicization of the U.S. prison. The civil rights movement, the Vietnam War, the student movement, and the law and order politics of the 1960s all had an impact on the men and women in prisons. Not only were politically astute leaders of the black and student movements in and out of prison themselves, but much of the prison population was increasingly politically aware...Recurring political trials such as the trial of the Chicago Seven were on the evening news. Black, Hispanic, Native American, and white political organizations such as the Black Panther Party, Weathermen, and the American Indian Movement had members both inside and outside of prison, as radical political actions came to routinely result in prison time (2010: 1 ).

Indeed, the 1970 s prison system was moving away from the concept of a 'total institution' as it had been previously conceived by Erving Goffman, (1961: 6) toward an open-system environment where societal influences and social issues drifted in and out of the corrections system along with its inmates. The New York State Special Commission on Attica (the McKay Commission) agreed, concluding 'the influence of the Panthers was a pervasive factor that led to the prison riot' (Williams, 1997: 16). The 70s political climate is also referenced as a riot causal factor in prison management literature (Stojkovic, Kalinich, and Klofas, 2008). Contributing to the social and political turmoil reflected in the Attica Prison riot was the conservative law and order stance of government agencies - among these the New York corrections system, the state police, and Governor Nelson Rockefeller.

Along with the system of racism inherent within Attica Prison, Starr draws attention to the McKay Commission's findings that the (New York) prison system was utterly incapable of 'meeting the psychological and social needs' of its inmates (1973: 32). Conditions at Attica had scarcely changed 'since the opening of New York State's Auburn prison in 1819' (32). This meant poor food, 'deadening routine,' arbitrariness in, and lack of, parole decisions, and what Starr refers to as an unyielding 'system of habit' that was unable to change with the times (32).

Strict law and order was a central feature of this system of habit - a tough stance that permeated the corrections and police systems and the Republican conservatism existing in 1971 New York. On the morning of September 13th and after refusing to travel to Attica to meet with a team of inmate negotiators, Governor Nelson Rockefeller ordered state police to retake Attica. Six minutes was all the time it 
took several hundred New York State troopers to reclaim Attica, leaving 43 dead (Light, 1995). President Richard Nixon praised Rockefeller's decision to deploy state troopers as 'a fabulous job' and 'a beautiful operation' that 'saved a lot of guards' (Roberts, 2011:1). In the wake of Attica the doctrine of 'crushing power' for riot control began to be reexamined (Garson, 1972).

Also reexamined were corrections department officials' claims of rioting inmates murdering hostages by slitting throats and castrating another hostage (The Nation, 1971). As facts unfolded, claims of excessive force emerged against state troopers who were found to be at fault for inmate and hostage deaths. Rioting inmates had not slit throats. The castration claim proffered by government officials also proved a blatant falsehood (Benjamin and Rappaport, 1974; Columbia Journalism Review, 1971). In one of the very few media-related articles pertaining to the Attica Prison riot, editors at the Columbia Journalism Review examined the 'breakdown in coverage' that 'came under the pressure of official misinformation after the assault on the prison by state forces' (1971: 2).

\subsection{Attica and the Media}

Mahan and Lawrence (1996) have examined the role of the media in prison riots although their study did not examine news representation of prison riots, per se. In terms of Attica, these authors found that 'once the siege was underway, rioters demanded access to the media as a means of making public any promises made to them by the state' (428). Among others, inmates requested the presence of Tom Wicker ${ }^{2}$, a New York Times editor and columnist.

Wicker's presence as a negotiation observer during the Attica riot provided him the unique opportunity to report on what would become a historical event. Wicker's subsequent account of events in A Time to Die (1980) captured the anxieties and policy failures in real-time. Chronicling the event as it unfolded, Wicker viewed the escalating tumult and impending train wreck of political philosophies that culminated from the overall era of clashing race relations and civil unrest. Wicker's perspective, rooted in

2. A Pulitzer Prize winner, Tom Wicker died in November, 2011 during the 40th anniversary year of the Attica Prison riot (McFadden, 2011). the social unrest of the time, repeats the previous and common themes of Attica resonating as a flashpoint in American race relations and the Black Nationalist Party's call for freedom (Williams, 1997). As in the McKay Commission's official report, Wicker found the underlying causation of the riot to be a spontaneous response to the inequities of race and class fueled by the deprivation of the prison setting.

\subsection{Attica - Then and Now}

Since September, 1971, causal factors of the Attica Prison riot have been widely discussed by academics and social critics. Academics, such as Useem and Kimball, have more finitely examined 'what Attica "meant"' especially with regard to prison conditions and needed reform (1989:20). A New York State Special Commission was convened and an official report has been written and subsequently critiqued by legal writers like Murton (1973) and Bell (1985). Attica negotiation observers, like Wicker, have presented their accounts (1975). Attica has since been compared to other prison riots in the academic literature especially with respect to prison control and management (Garson, 1972; Carrabine, 2005; Useem and Kimball, 1989; Mahan, 1994; Stojkovic, Kalinich, and Klofas, 2008). Media's eagerness to report inaccuracies regarding the killing of inmates and hostages by state agents has been criticized as was Rockefeller's refusal to go to Attica (Wicker, 1975; Columbia Journalism Review, 1971; Roberts, 2011; ). The inhumane retaliatory treatment of inmates by prison guards after the Attica Prison riot has been examined and litigated although the State of New York 'has never admitted that it used excessive force' or that 'its troopers killed inmates and guards' (Thompson, 2011: 3). Forty years later, Attica remains the seminal prison riot and is the topic of new historical research and writing (Thompson, 2011). What has not been expressly examined is the ways in which the newsprint media of the day informed and influenced the American public via its social construction of the Attica Prison riot. The purpose of this research is to fill that void.

\subsection{Constructed Meaning and Frame Analysis}

Exploring constructed reality by way of stakeholder's presentation is rooted in interpretivism. The primary task of researchers 
using an interpretive framework is to present the interpretations of reality that are being presented by the people being studied (Geertz, 1987; Young, 1996). In addition, cultural studies theorists argue that the ideology of a group is produced and reproduced within the interpretive packages of individuals within those groups (Frow, 1995; Hall, 1980; Street, 2005; Williams, 1977). Transformation and competition between differing ideological perspectives posited by these groups occur through the narrowing and expanding of discourse surrounding the dispute in question (Barak, 1994; Mather \& Yngvesson, 1980-81). Frame analysis, rooted in phenomenological explorations of how individuals understand things as "real" argues that interaction operates within what are considered acceptable frames (James, 1950; Goffman, 1974). Previous analytical constructivist and frame perspectives have focused on how the media obtain promoted meanings, present crime to the public and in turn how the public perception of crime is shaped by these frames (Barak, 1994; Beckett, 1997; Chermak, 1997; Entman, 2004; Ericson, 1995; Fishman, 1978; Goode and Ben-Yehuda, 1994; Reiman, 1995; Surette, 1992). Earlier analytical conclusions from constructivist and frame perspectives reveal patterns of decontextualization and simplification of complex social problems combined with resulting policy solutions rooted in concentrated regulation and further control of specific populations (Best, 1995; Cohen, 1980). Recent examination of social problems, moral panics, and the resulting public policy draw attention toward symbolic discourse and competing moral politics meted out within a politically fragmented environment of proliferating media (Garland, 2008).

The process of framing takes place through symbolic discourse by means of what Gamson (1992) refers to as interpretive packaging. Through the use of metaphors, visuals, stories, and numbers (referred to as "condensing symbols") core frames are presented on specific issues. The subsequent interpretive packages pay specific attention to particular worldviews and assumptions held by institutions and actors involved in the competing discourse (Beckett, 1997; Gamson, 1992; Gamson and Stuart, 1992). These packages display rhetorical devices (i.e., exemplars, catchphrases, depictions, and principles) ${ }^{3}$ that suggest particular frames and courses of policy appropriate to address an issue. When this competing symbolic discourse takes place within media narratives, sponsorship of particular ideological and political viewpoints are embedded within policy positions promulgated by official source attribution (Beckett, 1997; Chermak, 1997; Gies, 2011; Van Gorp, 2011). In other words, media work as forces that shape presentation of political meaning. Entman argues competing frames represent differences which are meted out in a cascading activation model whereby substantive and procedural frames are presented with the capacity to stimulate support or opposition toward political sides (2004: 5-7). ${ }^{4}$ Analyzing interpretive packages provides an opportunity to reveal the magnitude of which particular assumptions are presented to the reading public and how often. The capacity to stimulate support or opposition for competing frames is dependent upon the degree of cultural resonance presented within the interpretive packages. While the magnitude of a particular interpretive package's presentation provides an indication of its prominence, cultural resonance taps into the degree of emotive salience for the recipient of particular frames (Entman, 2004; Van Gorp, 2005).

Textual analysis of source attribution or claims-maker identity within media narratives provides a thick description as to the extent of subjectivity being presented by a particular news source and, to that extent, has the capacity to establish support for policy and to shape public opinion accordingly (Mason, 2007). The perspective of thick description, emanating from the ethnographic anthropology literature, seeks to explain the culture of people as an ensemble through the exploration of the depth of exchange between participants and its underlying meaning to those participants (Geertz, 1987).

Applying a constructivist and frame perspective (as a multi-faceted approach) to

3. Katherine Beckett used a similar methodological approach in her analysis of framing crime and drug news stories and the use of official sources (Beckett, 1997: 62-78; Beckett, 1995).

4. Entman's (2004: 5-6) cascade model of framing includes substantive and procedural frames. Substantive frames define effects or conditions as problematic, identify causes, convey moral judgment and endorse remedies. Procedural frames suggest evaluations of political actor legitimacy based on representativeness, technique and success. 
textual analysis is what Altheide (1987) argues is the basis of ethnographic content analysis. As Ferrell, Hayward, and Young (2008: 189) point out in reference to this method of analysis, a multi-faceted approach can "identify the textual patterns while recognizing the fluid dynamics of inter-textuality and inter-subjectivity within which such patterns take place." As a method of critical analysis, interpretive packages, their subsequent frames, and claims-makers allow for an in-depth understanding of the assigned political and ideological meaning that institutions attach to events and individuals. Thus, the reification of boundaries, sides, winners, losers, criminals, and non-criminals are defined through social and cultural processes that are separate from the act itself (Presdee, 2000). The processes of media emphasis, as well as overemphasis, through editorial board perspectives of newsworthiness combined with the institutionalization of crime reporting serve to provide narrow interpretations of events that many times fit neatly within the pre-conceived perspectives of the particular audiences absorbing news products. News coverage of the 1971 Attica Prison riot serves as a seminal example for analysis - a perfect storm of newsworthiness, competing frames, and constructed meaning.

\section{DATA AND METHOD}

This study examines newsprint media representation of the Attica Prison riot. Applying qualitative frame analysis across three different news sources, 217 news articles from September 11th, 1971 through December 31st, 1972 were analyzed. These news articles provide a representation of the various discourses and claims-makers involved in the prison uprising. Using Boolean searching across Proquest's historical database systems the terms "Attica Prison," "prison riot," and "prison uprising" were searched within headings and narratives across the years 1971 and 1972 for the New York Times, Chicago Tribune and Chicago Defender.

Table 1

Newspaper Textual Data Stratified by Source and Month - September 1971 to December 1972

\begin{tabular}{|c|c|c|c|c|c|c|c|c|c|c|c|c|c|c|}
\hline $\begin{array}{c}\text { Newspaper } \\
\text { Source }\end{array}$ & $\operatorname{sep}_{71}$ & $\begin{array}{c}\text { Oct. } \\
71\end{array}$ & $\begin{array}{c}\text { Now: } \\
71\end{array}$ & $\begin{array}{c}\text { Dec. } \\
71\end{array}$ & $\begin{array}{c}\operatorname{len} \\
72\end{array}$ & $\begin{array}{c}\text { Feb. } \\
72\end{array}$ & $\begin{array}{c}\mathrm{Mer}: \\
72\end{array}$ & $\begin{array}{c}\text { Apr. } \\
72\end{array}$ & $\begin{array}{c}\mathrm{Moy} \\
72\end{array}$ & iun & $\frac{M}{n}$ & $\begin{array}{c}\text { Awg: } \\
72\end{array}$ & $\begin{array}{c}\text { Sepi-Dec. } \\
72\end{array}$ & Tetal \\
\hline Nr Timen & $\mathrm{N}=79$ & $N=18$ & $\mathrm{~N}=4$ & $N=1$ & - & $\mathrm{N}=2$ & $\mathrm{~N}=2$ & $N=11$ & $N=1$ & $\mathrm{~N}=1$ & - & - & $N=1$ & $\begin{array}{l}N=120 \\
55.3 \mathrm{~N}\end{array}$ \\
\hline $\begin{array}{l}\text { Chicago } \\
\text { Tribune }\end{array}$ & $\mathrm{N}-28$ & $\mathrm{~N}-3$ & $N-3$ & $N-3$ & $m$ & $N-1$ & $N-1$ & - & $N-2$ & - & $N-1$ & m. & $m$ & $\begin{array}{c}N=42 \\
19.46 \\
\end{array}$ \\
\hline $\begin{array}{l}\text { Chicago } \\
\text { Dufender }\end{array}$ & $\mathrm{N}=27$ & $\mathrm{~N}=3$ & $N=1$ & $N=1$ & m. & $=$ & $\mathrm{N}=1$ & $N=S$ & $\mathrm{~N}=2$ & - & $N=1$ & $\mathrm{~N}=1$ & $N=13$ & $\begin{array}{l}N=55 \\
25.3 \mathrm{~N}\end{array}$ \\
\hline Total & $\begin{array}{l}N-134 \\
61.8 \%\end{array}$ & $\begin{array}{l}N-24 \\
11.026\end{array}$ & $\begin{array}{l}\mathrm{N}-\mathrm{8} \\
3.7 \%\end{array}$ & $\begin{array}{l}N-5 \\
2.3 * 6\end{array}$ & $m$ & $\begin{array}{l}N-3 \\
1.45\end{array}$ & $\begin{array}{l}N-4 \\
1.8 \times 6\end{array}$ & $\begin{array}{l}N-16 \\
7.446\end{array}$ & $\begin{array}{l}N-5 \\
2.3 \%\end{array}$ & $\begin{array}{l}\mathrm{N}-1 \\
47 \% 6\end{array}$ & $\begin{array}{l}\mathrm{N}-2 \\
92 \%\end{array}$ & $\begin{array}{l}\mathrm{N}-1 \\
47 \mathrm{~N}\end{array}$ & $\begin{array}{l}N-14 \\
6.5 \%\end{array}$ & $\begin{array}{r}N-217 \\
100 \mathrm{~N}\end{array}$ \\
\hline
\end{tabular}

The New York Times was selected as a reliable indicator of national, as well as New York State and New York City news (Chermak and Weiss, 1998; Danielan and Reese, 1989). The Chicago Tribune and Chicago Defender were chosen for two reasons. First, these newspapers represent news coverage of the Attica Prison riot outside of the east coast geography of New York but within the second most populous urban environment of the time period (Hobbs and Stoops, 2000). Second, these two Chicago based daily newspapers have traditionally served a dissimilar reading clientele. The Chicago Tribune has historically served a readership consisting of middleclass, urban, and suburban Chicago, Cook County and collar-county residents while the Chicago Defender has historically been one of the nation's most influential black weekly newspapers serving Chicago's urban African-American community (Chicago Defender, 2011; Wendt, 1979). The analysis of these three newspapers provides an avenue to determine differences in news presentation across demographically different readerships, not only nationally with regard to the New York Times but also culturally within the large metropolitan setting of Chicago. 


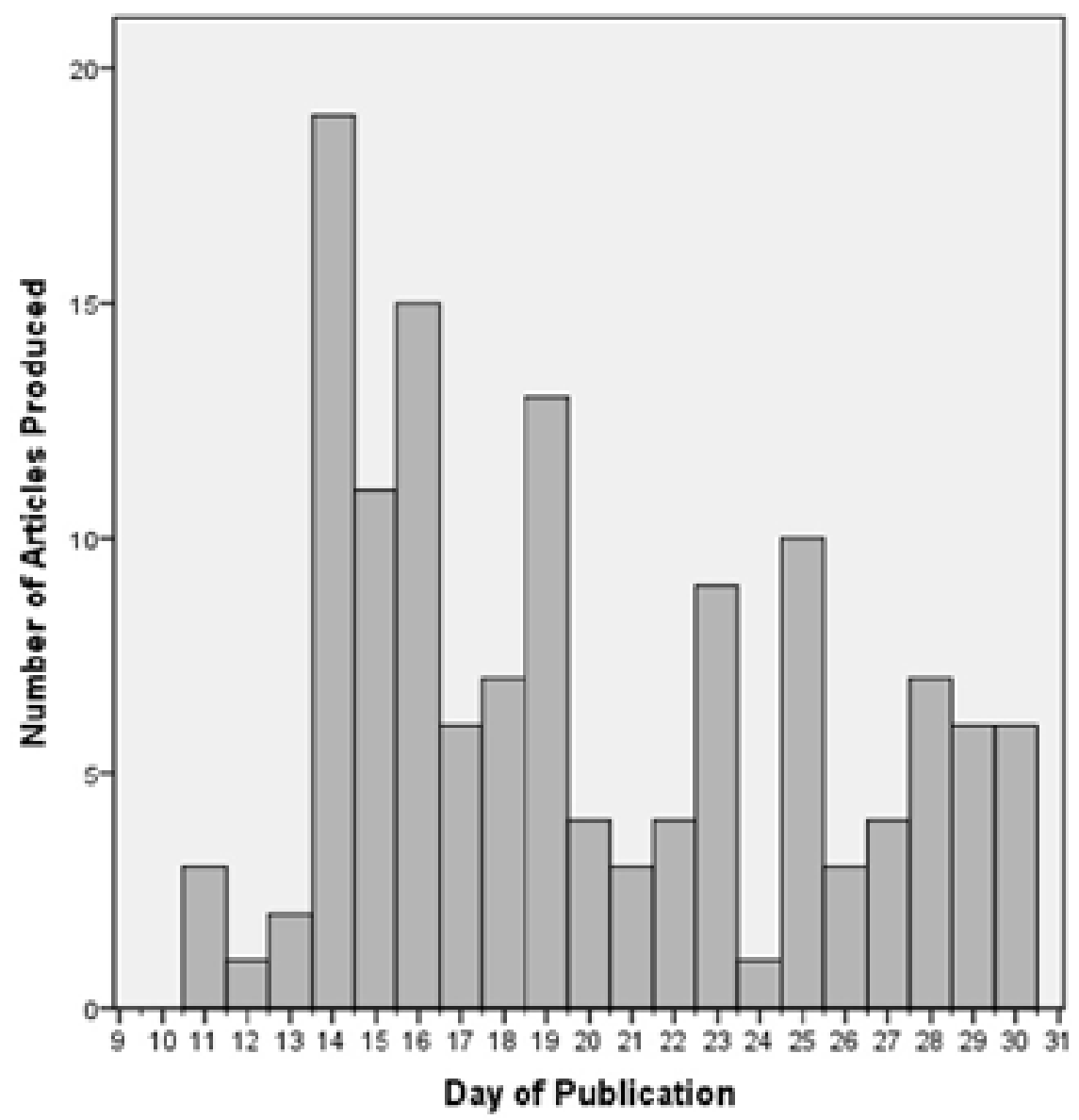

The data population stratified by news source and month between September 1971 and December 1972 revealed a total of 217 $(\mathrm{N}=217)$ news articles published across the three newspapers. Almost $62 \%$ of these stories were published within the month of September 1971 and almost $72 \%$ of the narratives were published by the end of October, 1971. Saturation of news articles across all three newspapers diminished substantially in the months following the Attica Prison riot. News article saturation was then analyzed by day for the month of September, 1971 revealing a peak number of articles $(\mathrm{N}=18)$ published on September, 14 th $^{5}$ with a general decline thereafter.

Discourse and claims-makers were analyzed across the September, 1971 articles $(\mathrm{N}=134)$. Employing a coding scheme rooted in the sociological constructs of punishment, prisons, and prisoners, news text was analyzed via hand coding. The unit of analyses within the media text consisted of two levels. Level one was comprised of the media articles, per se. Media articles were coded for prominence of particular issue frames. The packages of issue frames and examples of differing frames are provided in Table 2 below. The operationalization of these frames into a coding scheme required the development of a matrix of prison riot issue packages identifying and describing core frames (see appendix). These interpretive packages provide condensing symbols focusing on specific worldviews and assumptions held by institutions and actors involved in the event, including the media outlets and public who were eventually presented with these packages (Gamson, 1992; Gamson and Stuart, 1992).

5. On the morning of September 13, New York State Police, acting on the orders of Governor Nelson Rockefeller, stormed and retook Attica Prison (Bell, 1985). 
Examples of the coinciding positions, exemplars, catchphrases, depictions, roots, and principles of the different issue frames are numerous. ${ }^{6}$ For instance, within the order and control frame different catchphrases included: order must be restored, legal police action, and force necessary to quell disorder. These catchphrases were included within exemplars whereby data, incidents, and stories were presented within the media narrative that bolstered the frame of order and control. This frame also included depictions of chaos instituted by radical prisoners and inmate leaders orchestrating the hostage taking and rioting in Attica Prison. This is substantively different than the captive as victim frame. Within this frame catchphrases such as convicts' massacred, concentration camp for blacks, and organized manslaughter were visible. Policy solutions applying this frame were focused on obligations to address government cover-ups and violations of human rights as opposed to maintaining order and control.

Table 2

Framing Matrix

\begin{tabular}{|l|l|}
\hline Package & Issue Frame \\
\hline $\begin{array}{l}\text { 1. Order and } \\
\text { Control }\end{array}$ & $\begin{array}{l}\text { The issue is how to provide order, safety, control, and respect for authority within } \\
\text { a population of rioting inmates who are holding hostages. }\end{array}$ \\
\hline $\begin{array}{l}\text { 2. Rights of the } \\
\text { Inmates }\end{array}$ & $\begin{array}{l}\text { The issue is how to address the due process and civil rights of Attica inmates as } \\
\text { afforded under the Constitution. }\end{array}$ \\
\hline $\begin{array}{l}\text { 3. Root Causes } \\
\text { of the Event }\end{array}$ & $\begin{array}{l}\text { The issue is social stratification of Attica inmates by race and class, magnified by } \\
\text { social unrest in broader American society and inadequacies of the prison system. }\end{array}$ \\
\hline $\begin{array}{l}\text { 4. Attica the } \\
\text { Community }\end{array}$ & $\begin{array}{l}\text { The issue is individuals from the outside environment depicting the Attica prisoner } \\
\text { rebellion in a sensationalized manner inconsistent with locally produced actuality. }\end{array}$ \\
\hline $\begin{array}{l}\text { 5. Attica War and } \\
\text { Struggle }\end{array}$ & $\begin{array}{l}\text { The issue is the Attica prisoner as a political activist raising awareness of prison } \\
\text { conditions and the realities of prison captivity. }\end{array}$ \\
\hline $\begin{array}{l}\text { 6. The Captive as } \\
\text { Victim }\end{array}$ & $\begin{array}{l}\text { The issue is the social construction of inmates as victims worthy of sympathy and } \\
\text { honor for raising awareness of prison brutality and cover-ups by government } \\
\text { officials. }\end{array}$ \\
\hline
\end{tabular}

a. See appendix for the full framing matrix.

After initial coding of the differing packages presented within the media articles, attributions were linked to the differing claims-makers as a second level of analysis. The approach of linking the frames to specific claims-makers as a second analysis was conducted in previous research by Chermak (2002) in his investigation of militias in the news. The analytic purpose of this twoprong approach provided an analysis that not only explored the frames being presented but which frames were presented by which claims-makers and to what extent by the differing news sources. Sponsorship of ideological driven public policy approaches and media source attribution have been linked to the shaping of public perceptions of criminal justice issues in previous research

6. For a further example of this operational scheme see Beckett, K. (1997). Making Crime Pay: Law and Order in Contemporary American Politics. New York: Oxford University Press.
(Ericson, Baranak, and Chan (1989), Beckett, 1995 \& 1997, Chermak, 1997 \& 2002; Chermak and Gruenwald, 2006).

\subsection{Reliability and Validity Measures}

Reliability or coding stability within the media analysis was achieved by establishing a pilot test of coding across a small sample of the data population. Inter-rater reliability measures were applied through multiple observers trained to use the framing matrix of prison riot issues. ${ }^{7}$ Agreement between the independent coders was measured using the agreement coefficients of Scott's pi and Cohen's Kappa. While the percentage agreement between the two groups of coders revealed a score of .77, the more precise agreement coefficients revealed a Scott's pi score of .68 and a Cohen's Kappa of .69. In addition to measuring consistency among viewers through the use of multiple observers, consistency over time was 
realized using a test-retest method. Coefficients ranged between .66 and .67 on the Scott's pi score and .67 and .68 on the Cohen's Kappa score. ${ }^{8}$ The results of synchronic (inter-rater), as well as diachronic (test-retest) methods of reliability testing verify the efficacy of the coding scheme.

Face validity, construct validity, and criterion related validity were strengthened through the implementation of a framing matrix (appendix) that was adapted from previous research concerning ideological concepts of punishment, prison riots and prisoners (Walsh, 2012). Content validity of categories in implicit concept analysis, in particular, was achieved by using multiple classifiers documented within the framing matrix. Multiple catchphrases were searched for within the media data that were conceptually linked to the differing packages. For example, the rights of the inmates package was coded from narratives that focused upon legal protection of prisoners, fair treatment and constitutional rights. These classifiers provided a comprehensive representation of the theoretical tenets of inmate rights. Using multiple classifiers, all issue packages were broadened to include differing linguistic word choices that were implicit in ideological concepts.

\section{ANALYSIS AND FINDINGS}

The study findings are introduced in two sections. First, the frequency of frames across September, 1971 news articles are presented. Further presentation disaggregates the September news stories by the differing news sources with differences and similarities highlighted. Section one concludes with an examination of issue packages, by week, with an analysis of the changing trajectory of the Attica Prison riot as it unfolded in media presentation. Section two examines the percentage of articles sourced through differing claims-makers. In

7. Two differing groups of advanced undergraduate students were trained separately on the use of the coding scheme and the prison riot signature matrix. These students then coded the same newsprint articles selected randomly from the media data. The two independent scorer groups applied presence and absence coding in regard to the six packages stipulated within Table 2 and the Appendix.

8. The use of Scott's pi and Cohen's Kappa agreements of coefficients are generally accepted systematic reliability approaches across content analysis methods (Lombard, Snyder-Duch and CampanellaBracken, 2004; Neundorf, 2002; Wimmer and Dominick, 2006). addition, the claims-makers are then linked to the particular issue packages that were posited through news sources. Finally, each of the three news sources are presented and analyzed in conjunction with the dominant frames they portrayed to readers via source attribution.

\subsection{Frame Analysis Across September, 1971}

Across the 134 news articles published in September 1971, 339 issue packages were presented to the reading public. While all six issue packages were presented throughout the month of September, the three most common issue packages across all three newspapers en masse were the packages of order and control, Attica the community and Attica war and struggle. The least presented frame was the rights of inmates issue package. Table 3 indicates a relatively even distribution of issue packages with, at the very least, a manifest presentation of the journalistic mantra that 'all sides' were receiving coverage of the event.

Table 3

Attica Issue Packages Presented Across Newspapers September 1971

\begin{tabular}{|l|l|l|}
\hline & Packages & $\begin{array}{l}\text { Frequency } \\
\text { of Presented } \\
\text { Frames }\end{array}$ \\
\hline 1. & Order and Control & 67 \\
\hline 2. & Rights of the Inmates & 38 \\
\hline 3. & Root Causes of Event & 55 \\
\hline 4. & Attica the Community & 65 \\
\hline 5. & Attica War and Struggle & 66 \\
\hline 6. & The Captive as Victim & 48 \\
\hline
\end{tabular}

Disaggregating issue packages by the three differing news sources revealed substantive differences in presentation of issue packages by newspaper and, subsequently, reader impression of the event. While multiple frames were presented within the coded news stories, Table 4 provides the percentage distribution of frames across the 79 news articles published by the New York Times. 
Table 4

Representation of Frames within Articles by Newspaper

\begin{tabular}{|c|c|c|c|}
\hline Packages & $\begin{array}{c}\text { N.Y. Times } \\
\text { Representation } \\
\text { (N=79) }\end{array}$ & $\begin{array}{c}\text { Chicago Tribune } \\
\text { Representation } \\
\text { (N=28) }\end{array}$ & $\begin{array}{c}\text { Chicago Defender } \\
\text { Representation } \\
\text { (N=27) }\end{array}$ \\
\hline Order and Control & $54.4 \%$ & $57.1 \%$ & $33.3 \%$ \\
\hline Rights of Inmates & $29.1 \%$ & $32.1 \%$ & $22.2 \%$ \\
\hline Root Causes of Events & $45.6 \%$ & $28.6 \%$ & $44.4 \%$ \\
\hline Attica the Community & $55.7 \%$ & $53.6 \%$ & $25.9 \%$ \\
\hline Attica War and Struggle & $48.1 \%$ & $50.0 \%$ & $55.6 \%$ \\
\hline The Captive as Victim & $39.2 \%$ & $28.6 \%$ & $40.7 \%$ \\
\hline
\end{tabular}

The highest percentage presentation of frames across New York Times stories included issue packages presenting frames of Attica the community and order and control. An example of a New York Times article coded under the issue package of Attica the community is represented below:

In Junior-Senior Attica Central School, the students - many of them children of guards at Attica Prison-are just beginning to shake off the shock of the uprising and bloody assault in which fathers of some of their classmates were killed or faced death. Scott Gerhardt, president of the student council, denied the town was racist. He said: "It is only natural that many should feel bitter against the prisoners who organized the uprising, they had fathers there" (Schumach, 1971: 26).

This Attica the community frame is qualitatively different than frames coded under the issue package of order and control as evidenced in the following excerpt:

Presidents of the city's wardens' and corrections officers' associations called yesterday for legislation to make the taking of a hostage in a prison riot a crime punishable by life imprisonment. "The senseless and brutal killing of 10 correctional officers at Attica Prison demands that immediate steps be taken to insure the safety of corrections officers and put inmates on notice that such conduct will not be tolerated" (Burks, 1971: 31).

Attica the community and order and control frames were presented in more than half of the New York Times news articles.
Comparison of the Chicago Tribune's to the New York Times' representations of frames within news articles revealed an even higher percentage of order and control within Tribune articles. As example, is this sentiment reflected in a Chicago Tribune article: 'The County Jail and the House of Corrections and the prisoners at both institutions are being searched for weapons every other day under a new policy put into effect following the Attica Prison riots, it was learned yesterday' (Wood, 1971: p. 2). Coupled with its higher percentage of the order and control package, the Tribune presented frames associated with the root causes of the event $17 \%$ less often and the captive as victim $10 \%$ less often than the New York Times. Also, the Chicago Tribune had the highest percentage representation of the rights of inmates package across all three news sources. An illustration of the rights of inmates package within the Chicago Tribune included the following: 'Eight lawyers from civil rights groups visited Attica Correctional Facility today to investigate charges that inmates were beaten following the assault that broke the five day uprising' (Chicago Tribune, 1971: A1).

The Chicago Defender's representation of the order and control package across the twentyseven articles published in September was more than $27 \%$ less than the New York Times and the Chicago Tribune. The highest percentage of the Attica war and struggle package occurred within Chicago Defender news articles. This Chicago Defender example highlights the extreme difference in framing the Attica Prison riot dependent upon the news source:

The rebellion was a protest against inhuman treatment, repression, terror and unbearable living conditions. The prisoners, after repeated 
requests for improvement of conditions, had painstakingly arrived at the conclusion that they would rather die than continue to submit to discipline in which they were treated like beasts (Attica Senseless Killings, 1971: 19).

Analysis indicated the Chicago Defender was aligned more evenly with the New York Times concerning the root causes of the event package (Defender, 44.4\%; NY Times, 45.6\%) and the captive as a victim package (Defender, 40.7\%; NY Times, $39.2 \%$ ) as opposed to the Chicago Tribune's $28.6 \%$ root causes packaging and $22.6 \%$ captive as a victim packaging.

Attica Prison riot issue frames during September were also examined across the differing news sources by week. The Attica the community, order and control, and Attica war and struggle issue packages were manifest during the first week of news coverage. This time period included the prisoner take over, hostage negotiation, and subsequent violent government reaction to the riot.

The captive as victim frame was most evident during week two of the news coverage when investigations of improper handling of the prison riot along with an overall questioning of prison conditions were at their height. An example of week two, the captive as victim framing within the New York Times is portrayed here:

Another committee member, Bobby Seale, national chairman of the Black Panther Party, said in a separate interview outside the meeting room that the Governor and President should be indicted for "first degree murder" in connection with the Attica killings (Clarity, 1971: 60).

The root causes issue package, while constituting just over $16 \%$ of the total issue packages, retained a consistent amount of presentation over the three week news cycle. Examples included frames such as, 'Attica Prison is a prime example of what happens when we fill our jails to the overcrowding point because we are arresting and imprisoning people that belong in medical treatment facilities' (Pace, 1971, 35). As the complexity of the riot unfolded and as the coverage across all three news sources receded, the issue packages reached an even distribution of frame presentation across packages.

Table 5

Attica Issue Packages Presented across Newspapers by Week and Type - September 1971

\begin{tabular}{|c|c|c|c|c|c|c|c|}
\hline & $\begin{array}{c}\text { Order } \\
\text { and } \\
\text { Control }\end{array}$ & $\begin{array}{l}\text { Rights of } \\
\text { Inmates }\end{array}$ & $\begin{array}{l}\text { Root } \\
\text { Causes }\end{array}$ & $\begin{array}{c}\text { Closed } \\
\text { System } \\
\text { Perspective }\end{array}$ & $\begin{array}{l}\text { Open System } \\
\text { Perspective }\end{array}$ & $\begin{array}{c}\text { Captive as } \\
\text { Victim }\end{array}$ & $\begin{array}{c}\text { Frames } \\
\text { Presented } \\
\text { by Week }\end{array}$ \\
\hline $\begin{array}{c}\text { Week } 1 \\
\text { Sep. (11-17) }\end{array}$ & 32 & 14 & 21 & 33 & 32 & 14 & 146 \\
\hline $\begin{array}{c}\text { Week } 2 \\
\text { Sep. (18-24) }\end{array}$ & 20 & 8 & 17 & 17 & 19 & 21 & 102 \\
\hline $\begin{array}{c}\text { Week } 3 \\
\text { Sep. }(25-30) \\
\end{array}$ & 15 & 16 & 17 & 15 & 15 & 13 & 91 \\
\hline Total & $\begin{array}{c}67 \\
19.8 \%\end{array}$ & $\begin{array}{c}38 \\
11.2 \%\end{array}$ & $\begin{array}{c}55 \\
16.2 \%\end{array}$ & $\begin{array}{c}65 \\
19.2 \%\end{array}$ & $\begin{array}{c}66 \\
19.4 \%\end{array}$ & $\begin{array}{c}48 \\
14.2 \%\end{array}$ & $\begin{array}{c}339 \\
100 \%\end{array}$ \\
\hline
\end{tabular}

$(\mathrm{N}=339)$

\subsection{Claims-Maker Analysis Across September, 1971}

Section two of the findings examines the claims-makers sourced by the three newspapers during the month of September 1971. Across the 132 news articles published in September, 30.3\% of the news stories sourced Attica officials and their perspectives of the crises. Attica officials included New York Governor Nelson Rockefeller, New York Department of Corrections officials, and line-level correctional employees at Attica Prison. 
Table 6

Claims-Makers Sourced by Newspapers - September 1971

\begin{tabular}{|l|c|}
\hline & $\begin{array}{c}\text { Percentage of } \\
\text { Article Sourced } \\
\text { by Claims-Makers }\end{array}$ \\
\hline Attica Officials & $30.3 \%$ \\
\hline Activists & $28.8 \%$ \\
\hline $\begin{array}{l}\text { Media Writers/ } \\
\text { Columnists }\end{array}$ & $18.2 \%$ \\
\hline Outside CJ Officials & $16.7 \%$ \\
\hline Republican Politicians & $15.2 \%$ \\
\hline Democrat Politicians & $12.1 \%$ \\
\hline Inmates & $10.6 \%$ \\
\hline $\begin{array}{l}\text { Attica, NY Community } \\
\text { Members }\end{array}$ & $6.8 \%$ \\
\hline
\end{tabular}

$\mathrm{N}(332)$

Conversely, almost 29\% of the claims-making was through activists. Activists included local community members and the Black Panther Party. Media writers and columnists were sourced within $18.2 \%$ of the news stories. This percentage is a partial product of the fact that a few specific media writers, most notably Tom Wicker of the New York Times, and James Ingraham of The Michigan Chronicle ${ }^{9}$ were also negotiator observers inside the prison during the takeover. ${ }^{10}$ Outside criminal justice officials $(16.7 \%$ of the claims-makers) consisted of perspectives and opinions sourced from other correctional officials, criminal justice personnel, and criminal justice academics outside of the immediate Attica crises. Republican politicians (15.2\%) and Democratic politicians (15.2\%) were coded as such when the claims-makers were specifically identified as a member of a particular political party or when the claims-maker soundly identified with a political party on a national level. Examples of political party affiliates ranged from local congressional representatives from upstate New York and New York city and New York State Governor Nelson Rockefeller $^{11}$ to Vice President Spiro Agnew and President Richard Nixon. Inmates as claimants (10.6\%) included former Attica prisoners and former prisoners from other correctional facilities who were sourced. Attica, New York community members (6.8\%) were various Attica residents who provided accounts of the riot and its aftermath.

A further review of the claims-makers was conducted after disaggregating newspapers. These findings allowed for comparison within and across newspapers based on claims-makers sourced. In nearly $60 \%$ of the news articles, sourced claims-makers consisted of Attica officials and activists.

The New York Times presented these two categories of claims-makers in a relatively even distribution with only a $2.5 \%$ difference between the groups. Notably, when looking at the Chicagobased newspapers there was a clear difference in terms of claimants sourced. The Chicago Tribune posited Attica officials as claim-makers nearly $43 \%$ of the time $-12.6 \%$ above the overall percentage of $30.3 \%$. Conversely, the Chicago Defender presented Attica officials as claimsmakers the least - over ten percent $(10.3 \%)$ less than the $30.3 \%$ calculated across all three news sources. Another noted discrepancy was the Chicago Tribune's reduced sourcing of activists as

Table 7

Claims-Makers Sourced by Newspapers across News Articles - September 1971

\begin{tabular}{|l|c|c|c|}
\hline & $\begin{array}{c}\text { Attica Officials } \\
\text { Sourced }\end{array}$ & Activists Sourced & $\begin{array}{c}\text { Media /Columnists } \\
\text { Sourced }\end{array}$ \\
\hline $\begin{array}{l}\text { New York Times } \\
\text { (N=79) }\end{array}$ & $29.1 \%$ & $31.6 \%$ & $15.2 \%$ \\
\hline $\begin{array}{l}\text { Chicago Tribune } \\
(\mathbf{N = 2 8 )}\end{array}$ & $42.9 \%$ & $17.9 \%$ & $14.3 \%$ \\
\hline $\begin{array}{l}\text { Chicago Defender } \\
(\mathbf{N}=25)\end{array}$ & $20.0 \%$ & $32.0 \%$ & $32.0 \%$ \\
\hline $\begin{array}{l}\text { All News Articles } \\
(\mathbf{N}=132)\end{array}$ & $30.3 \%$ & $28.8 \%$ & $18.2 \%$ \\
\hline
\end{tabular}


claims-makers - nearly eleven percent (10.9\%) less than the $28.8 \%$ across all newspapers.

The percentage of news articles sourcing meia writers and columnists as claims-makers was skewed by stories produced by media reporters who served as negotiation observers within Attica Prison during the riot. The Chicago Defender relied the most heavily on opinion perspectives from regular Defender columnists during their presentation of the prison riot. The Defender proffered its own reporters and columnists more than twice as much as did the New York Times or the Chicago Tribune.

When assessing political party affiliated claims-makers by newspaper, the Chicago Tribune was the most likely of the three newspapers to use self-identified partisan politicians or nationally known partisan politicians as claimants. Republican politicians were claims-makers in over twenty-one percent (21.4\%) of news articles and Democratic politicians were claims-makers in almost eighteen percent (17.9\%) of Chicago
Tribune narratives. The New York Times sourced Republican and Democratic politicians equally within $13.9 \%$ of their Attica articles. Interestingly, the Chicago Defender sourced identifiable Republican politicians in $12 \%$ of their narratives yet did not source any identifiable Democratic politicians within their presentations. Also notable, the Chicago Defender did not source prison inmates or Attica, New York community members within the twenty-five news stories produced in the month of September 1971.

A final view of issue packages and claimsmakers was produced matching frames presented in conjunction with the claims-makers sourced for the September news narratives. The rationale was to determine what issue packages were most likely to be conveyed by particular claims-makers. Comparing these findings with the previous findings pertaining to which newspapers were most likely to use which claims-makers provided a mechanism for discerning differences in how the Attica Prison riot was portrayed to differing readership.

Table 8

Frames Presented and Claims-makers Sourced within Narratives - September 1971

\begin{tabular}{|c|c|c|c|c|c|c|c|c|}
\hline & $\begin{array}{c}\text { Attica } \\
\text { Officials }\end{array}$ & Inmates & Activists & $\begin{array}{c}\text { Outside } \\
\text { CJ } \\
\text { Members }\end{array}$ & $\begin{array}{c}\text { Media/ } \\
\text { Columnists }\end{array}$ & $\begin{array}{c}\text { Republic } \\
\text { Politicians }\end{array}$ & $\begin{array}{c}\text { Democrat } \\
\text { Politicians }\end{array}$ & $\begin{array}{c}\text { Attica NY } \\
\text { Community } \\
\text { Members }\end{array}$ \\
\hline $\begin{array}{c}\text { Order and } \\
\text { Control }\end{array}$ & $18.9 \%$ & $6.1 \%$ & $10.6 \%$ & $10.6 \%$ & $9.1 \%$ & $11.4 \%$ & $6.8 \%$ & $3.0 \%$ \\
\hline $\begin{array}{c}\text { Rights of } \\
\text { Inmates }\end{array}$ & 6.1 & 3.0 & 12.1 & 6.8 & 6.8 & 2.3 & 6.1 & 0.8 \\
\hline $\begin{array}{c}\text { Root } \\
\text { Causes }\end{array}$ & 9.1 & 8.3 & 12.9 & 5.3 & 12.9 & 5.3 & 5.3 & 1.5 \\
\hline $\begin{array}{c}\text { Attica the } \\
\text { Community }\end{array}$ & 19.7 & 6.1 & 11.4 & 8.3 & 9.1 & 9.8 & 6.1 & 5.3 \\
\hline $\begin{array}{c}\text { Attica War } \\
\text { Struggle }\end{array}$ & 18.9 & 6.8 & 14.4 & 6.8 & 9.8 & 7.6 & 6.8 & 3.0 \\
\hline $\begin{array}{c}\text { Captive as } \\
\text { Victim }\end{array}$ & 7.6 & 6.1 & 15.2 & 3.8 & 6.1 & 3.8 & 3.8 & 2.3 \\
\hline
\end{tabular}

What is evident from Table 12 is that, as a group, none of the claims-makers sourced by the newspapers where specifically beholden to one particular issue package. Yet, it is also clear that variation across claims-makers' perspectives of framing the Attica uprising does exist. The choice of differing claims-makers as news sources by specific newspapers was shaping the overall view of the Attica Prison riot for the reader. 


\section{DISCUSSION AND CONCLUSION}

The issue packages presented by the differing claims-makers are as much an exercise in what is presented as in what is not presented. For example, it is clear that when Attica officials were sourced as claims-makers the narratives purported were likely to revolve around issue packages of Attica the community, Attica war and struggle, and order and control. In addition, what the reader was less likely to be exposed to when Attica officials were sourced as claims-makers were issue packages concerning rights of inmates, the captive as victim and root causes of the event. When these findings are coupled with the earlier presentation of data indicating $42.9 \%$ of the Chicago Tribune articles sourced Attica officials within their narratives one can begin to intellectually unravel the power of framing. The Tribune sourced activist claimsmakers the least amount (17.9\%) of the three newspapers analyzed.

Within the Chicago Defender, activist claimsmakers were sourced in $32 \%$ of the narratives and media writers and columnists claims-makers were sourced within $32 \%$ of the narratives. Attica officials were claims-makers within Defender news stories across $20 \%$ of the narratives. Factoring the use of claims-makers across the results within Table 12 revealed Chicago Defender new stories promoted a view of the Attica Prison riot through less of an order and control lens and through more of the root causes of the event, rights of inmates and the captive as victim frames.

The New York Times use of claims-makers was the most even-handed amid the three newspapers. The Times provided relatively equal sourcing of Attica officials (29.1\%) and activists (31.6\%), and an equal distribution of political perspectives (13.9\%) across both parties as sourced claims-makers. While the claims-makers

\footnotetext{
9. The Michigan Chronicle similar to the Chicago Defender is an urban based African-American centric daily newspaper owned (as was the Chicago Defender) by the Sengstacke newspaper chain.
}

10. Tom Wicker's (1975) A Time to Die, New York: Quadrangle/ The New York Times Book Co. is considered the most definitive written chronicle of the Attica uprising.

11. Coding pertaining to Governor Nelson Rockefeller was contingent on the context of the news article - i.e., whether Governor Rockefeller was cited as a republican official or as an executive level administrator of the New York Correctional System.

12. Italics are in the original. themselves were positing or neglecting particular issue packages to a greater or lesser degree, the New York Times presented those voices equally.

The idea that media might impact thinking about prisoners and prisons among members of the public emanates from the larger swath of scholarship examining crime construction within media (Barak, 1994; Beckett, 1997; Chermak, 1997; Ericson, 1995; Fishman, 1978; Goode \& Ben-Yehuda; Mason, 2007; Mathiesen, 2001; Reiman, 1995; Surette, 1992). Taken as a whole, the media presentation of the Attica riot revealed a relatively even distribution of frames across the population of newspaper articles. Yet, how the Attica riot was constructed by differing newspaper media sources revealed differing levels of frame salience across divergent cultural geographies. When the unit of analysis (i.e. each particular news source) was narrowed, contextual differences in presentation were revealed. Identifying, analyzing and comparing local media construction and source attribution along with their contextual differences is an avenue to delve into the complexity of local ways of knowing. This approach is the essence of interpretivist media analysis within cultural criminology - a way to explore the 'real and representational as an issue runs its course' (Ferrell, Hayward and Young, 2008: 189). Drawing conclusions about the media presentation of Attica based upon the aggregation of all three news sources runs the risk of ecological fallacy. Instead, disaggregating the news sources provides the ability to begin examining a complex social phenomenon as it is interpreted locally and differentially across dissimilar cultural geographies. As Altheide (1996: 69) has argued, this is why 'the media are consequential in social life.'

\subsection{Frame Salience and Cultural Geography}

Particular historical narratives are driven to some degree by news salience across differing cultural geographies. Theses narratives provide portions of the reality of an event. Ideas of otherness and difference in regard to the Attica Prison riot narrative are evident when comparing the three news sources analyzed. When the competing realities across all three newspapers are presented, a broadening narrative of complex social issues is evidenced. Yet, singularly, differing media sources are not necessarily presenting a 
broadening narrative but are merely reaffirming, to some degree, narrowing conceptions of reality that fit the particular readerships pre-conceived ideas of the incident. Such 'fitting' is more evident across the two Chicago newspapers and their respective source attribution choices that lean toward particular conceptual perspectives of the event. At an extreme, competing narratives of partial reality can posit polemic interpretations of events. This process of narrowing is inherent at the intersection of news reporting and news marketing across differing cultural geographies. Within the comprehensive reporting of the Attica event we do not see a polemic presentation from any of the news sources but we do see a shading of reality which reinforces local ways of knowing. In essence, historical narratives are driven by news salience across differing cultural geographies. In accordance, local ways of knowing is the stuff of cultural anthropology, cultural studies and cultural criminology.

\subsection{Triggering Events, Differing Lenses and the Public Policy Agenda}

Triggering events, such as the Attica Prison riot, thrust broader political issues emblematic of that particular triggering event onto the active public policy agenda. While Attica was a horrendous event leading to the death of 'ten hostages and 29 inmates at the hands of corrections officers and state troopers' (Wicker, 1975:314), the subsequent battle for defining the broader issue of the role of government power within correctional settings was defined within the media representation of the triggering event. Examination of the media's role in the presentation of the Attica Prison riot, via the differing lenses of agenda-setters used as source material providers, indicated a framing shift throughout the three week time-period of news presentation. A particular falsehood originally presented to the media by government based claims-makers served to eventually broaden the media narrative surrounding Attica:

In this worst of recent American prison revolts, several of the hostages-prison guards and civilian workers-died when convicts slashed their throats with knives. Others were stabbed and beaten with clubs and lengths of pipes (Ferretti, 1971, p. 1).
Those cons didn't wait a minute. They just slit throats... I can only tell you it was a massacre... The goddamned fools just wouldn't give up. They were fighting us (Trooper Who led 1st Wave, 1971, p. 3).

Subsequent investigation of the riot revealed that none of the hostages had succumbed to knife injuries at the hands of inmates (Clarity, 1971, p. 60). Over a five day period beginning on September 14th, 1971, the fabrication, initiated by a trooper sergeant interviewed on the scene, was adopted and reinforced by correctional administrators. After the fabrication was negated and the truthfulness of government officials was open to question, a broadening of frames ensued within media presentations that included an increase of media perspectives associated with the captive as victim. These broadening perspectives reinforced a burgeoning prisoners' rights movement to the general media audience and bolstered the overall public skepticism of government that began in the 1960s.

The power of media presentation to shape local ways of knowing grows more complex each day. Local historical narratives are changing through access to social media and other forms of computer mediated communication (Holt, 2010; Shirky, 2011). The importance of methodological approaches that serve to peel back the layers of narrative development and connection between claims-makers and media source attribution is becoming more important and more complex in a global, technological environment. What is the role of news and media agencies in perpetuating a value system of partial reality that is desired by their particular consumers? Objectivity has the capacity to be shaded by subjective editorial decision making and source attribution that reinforces and defines particular world and local views of social problems. As Marshall McLuhan (2003: 290) noted, "the owners of media always endeavor to give the public what it wants, because they sense that their power is in the medium and not in the message or the program. ${ }^{12}$ 


\section{BIBLIOGRAFÍA}

- Altheide D (1996) Qualitative Media Analysis. Thousand Oaks CA: Sage.

- Apple RW (2006) Attica - A judgment on America. New Statesman, 16 October, p.62.

- Attica senseless killings. (1971) Chicago Defender, 16 September, p.19.

- Barak G (1994) Media, Process, and the Social Construction of Crime. New York: Garland Publishing.

- Beckett K (1995) Media depictions of drug abuse: The impact of official sources. Research in Political Sociology, 1995, (7): 161-182.

- Beckett K (1997) Making Crime Pay: Law and Order in Contemporary Ameri

- can Politics. New York: Oxford University Press.

- Best J (ed) (1995) Images of Issues. New York: Aldine de Gruyter.

- Bell M (1985) The Turkey Shoot. New York: Grove Press, Inc.

- Benjamin G and Rappaport SP (1974) Attica and prison reform. Proceedings of the Academy of Political Science, Governing New York State: The Rockefeller Years, 31, (3): 200-213.

- Burks E (1971) Prison officials here ask for stiffer penalties for inmates who riot. New York Times, 14 September, p.31.

- Carrabine E (2005) Prison riots, social order, and the problem of legitimacy. British Journal of Criminology, 2005, (45): 896-718.

- Chermak S (1997) The presentation of drugs in the news media: The news sources involved in the construction of social problems. Justice Quarterly 14 (4): 687-718.

- Chermak S and Gruenwald JA (2006) Domestic terrorism and the media. Justice Quarterly, 23 (4): 428-461

- Chermak S and Weiss A (2005) Maintaining legitimacy using external communication strategies: An analysis of police media relations. Journal of Criminal Justice, 33: 501-512.

- Chicago Defender (2009) About Us: History.
Available at: http://www.chicagodefender. com/article-1369-about-us.html

- Chicago Tribune (1971) Rights lawyers examine charges of beatings after Attica revolt. 20 September, p. A1.

- Clarity J (1971) Observers lay killings to "official intransigence." New York Times, 19 September, p. 60.

- Cohen S (2002) Folk Devils and Moral Panics: The Creation of the Mods and Rockers (3rd ed). New York: Routledge.

- Columbia Journalism Review Editors (1971) Looking back on Attica. Columbia Journalism Review, 10, (4): 2-3.

- Danielian L and ReeseS (1989) A closer look at intermedia influences on agenda setting: The cocaine Issue of 1986 . In shoemaker P (ed) Communication Campaigns About Drugs: Government, Media and the Public. Hillsdale, NJ: Erlbaum, 47-66.

- Entman R (2004) Projections of Power: Framing News, Public Opinion, and U.S. Foreign Policy. Chicago: University of Chicago Press.

- Ericson R (1995) Crime and the Media. Brookfield VT: Dartmouth Publishing.

- Ericson RV, Baranek PM and Chan, JBL (1989) Negotiating Control: A Study of News Sources. Toronto, Canada: University of Toronto Press.

- Ferrell J, Hayward K and Young J (2008) Cultural Criminology: An Invitation. Thousand Oaks, CA: Sage.

- Ferretti, F (1971) 'Like a war zone'. New York Times, 14, September, p.1.

- Fishman M (1978) Crime waves as ideology. Social Problems, 25: 531-543.

- Frow, J (1995) Cultural Studies and Cultural Value. Oxford: Clarendon Press.

- Gamson, W (1992) Talking Politics. Cambridge: Cambridge University Press.

- Gamson Wand StuartD (1992) Media discourse as a symbolic contest: The bomb in political 
cartoons. Sociological Forum 7 (1): 55-86.

- Garland D (2008) On the concept of moral panic. Crime, Media, Culture 4 (1): 9-30.

- Garson GD (1972) Force versus Restraint in Prison Riots. Crime \& Delinquency, 18:11-421.

- Geertz C (1987) Deep play: Notes on the Balinese cockfight. In Rabinow $\mathrm{P}$ and Sullivan W (eds) Interpretive Social Science: A Second Look. Berkeley, CA: University of California Press, 195-240.

- Gies L (2011) A villain's' charter? The press and the human rights act. Crime, Media, Culture, 7: 167-183.

- Goffman E (1961) Asylums: Essays on the Social Situtatin of Mental Patients and Other Inmates. NY: Doubleday.

- Goffman E (1974) Frame Analysis: An Essay on the Organization of Experience. Cambridge: Harvard University Press.

- Goode E and Ben-Yehuda N (1994) Moral Panics: The Social Construction of Deviance. Cambridge MA: Blackwell Publishing.

- HallS(1980) Cultural studies: Two paradigms. Media Culture and Society 2 (1): 57-72.

- Harring SL and Dowdall GW (2010). "Attica prison riots." The American Mosaic: The African American Experience. Available at: http://www.africanamerican2.abc-clio.com/.

- Hobbs F and Stoops N (2002) Demographic trends in the 20th century. U.S. Census Bureau, Census2000 Special Reports CENR-4. Washington D.C.: U.S. Government Printing Office.

- Holt, T. (2010) Exploring strategies for qualitative criminological and criminal justice inquiry using on-line data. Journal of Criminal Justice Education 21 (4): 466-487.

- James W (1950) Principles of Psychology: Vol. 2. New York: Dover.

- Light SC (1995) The Attica litigation. Crime, Law, and Social Change, 23, (3): 215-234.

- Lombard M, Snyder-Duch J and CampenellaBracken, C (2004) A call for standardization in content analysis reliability. Human Communication Research, 30: 434-437.
- Mahan S (1994) An "orgy of brutality at Attica and the "killing ground" at Santa Fe: A comparison of prison riots. In Braswell MC, Montgomery RH, Jr and Lombardo, LX (eds.) Prison Violence in America. Cincinnati, OH: Anderson Publishing Co., 253-265.

- Mahan S and Lawrence R (1996) Media and mayhem in corrections: The role of the media in prison riots. The Prison Journal, 76, (4): 420-441.

- Mason P (2007) Misinformation, myth and distortion: How the press construct imprisonment in Britain, Journalism Studies 8 (3): 481-496.

- Mather L and Yngvesson B (1980-81) Language, audience, and the transformation of disputes. Law and Society Review, 15: 775-821.

- Mathiesen T (2001) Television, public space, and prison population. Punishment and Society, 3 (1): 35-42.

- McFadden RD (2011) Tom Wicker, Times journalist dies at 85 . New York Times, 29 November. Available at: http://www. nytimes.com/2011/11/26/us/tomwicker-journalist-and-author-dies-at-85. html?pagewanted=all.

- McLuhan, M (2003) Understanding media: The extension of man. Corte Madera CA: Gingko Press.

- Murton, T (1973) Attica: The official report. The Journal of Criminal Law and Criminology, (64) 1: 494-499.

- Neuendorf K (2002) The Content Analysis Guidebook. Thousand Oaks CA: Sage.

- New York State Special Commission on Attica (1972) Attica: The Official Report of the New York State Special Commission on Attica. New York, NY: Bantam.

- Pace E (1971) Reform in 'victimless crime' laws urged at legislative hearing. New York Times, 14 September, p. 35.

- Presdee M (2000) Cultural Criminology and the Carnival of Crime. New York, NY: Routledge. 
- Reiman J (1995) The Rich Get Richer and the Poor Get Prison: Ideology, Class and Criminal Justice (4th ed.). Boston: Allyn and Bacon.

- Roberts S (2011) Rockefeller on the Attica raid, from boastful to subdued. New York Times, 12 September. Available at: http://www.nytimes.com/2011/09/13/ nyregion/rockefeller-initiallyboasted-to-nixon-about-attica-raid. $h t m l$ ? $r=2 \& s c p+3 \& s q+a t t i c a \& s t+c s e$.

- Schumach M (1971) Students in town of Attica are recovering from shock. New York Times, 24 September, p.26.

- Shirky C (2011) The political power of social media. Foreign Affairs 90: 28-41.

- Starr R (1973) Prisons, politics, \& the Attica report. Commentary, 55, (3): 31-37.

- Stojkovich S, Kalinich D and Klofas, J (2008) Criminal Justice Organizations: Administration and Management (4th ed.). Belmont CA: Wadsworth.

- Street J (2005) Politics lost, politics transformed, politics colonised? Theories of the impact of mass media. Political Studies Review, 3: 17-33.

- Surette R (1992) Media, Crime \& Criminal Justice: Images and Realities. Pacific Grove, CA: Brooks/Cole Publishing Company.

- The Nation (1971) Slaughter at Attica. 27 September. Available at: http://www.the nation.com/article/slaughter-attica

- Thompson HA (2011) The lingering injustice of Attica. The New York Times, 8 September. Available at: http:// www.nytimes.com / $2011 / 09 / 09 /$ opinion/the-lingering-injustice-of attica. html?_r=1\&ref=atticariots1971.

- Time (1972). The law: A year ago at
Attica. Time, 25 September. Available at: http://www.time.com/time/magazine/ article/0,9171,903593,00.html.

- Trooper who led first wave tells of grisly prison scene. (1971) Chicago Tribune, 14 September, p.3.

- Useem B and Kimball P (1989) States of Siege: U.S. Prison Riots, 1971-1986. New York: Oxford University Press.

- Van Gorp B (2005) Where is the frame?: Victims and intruders in the Belgian press coverage of the asylum issue. European Journal of Communication, 20: 484-507.

- Walsh J (2012) The Culture of Urban Control: Jails and Overcrowding in the Crime Control Era. Lanham, MD: Lexington Books.

- Wendt L (1979) Chicago Tribune: The Rise of a Great American Newspaper. Chicago IL: Rand McNally.

- Wicker T (1975) A Time to Die. New York, NY: Quadrangle.

- Williams R (1977) Marxism and Literature. New York: Oxford University Press.

- Williams YR (1997) American exported black nationalism: The student nonviolent coordinating committee, the black panther party, and the worldwide freedom struggle, 1967-1972. Negro History Bulletin, 60, (3): 13-20.

- Wimmer R and Dominick J (2006) Mass Media Research: An Introduction. Belmont CA: Wadsworth.

- Wood H (22 September 1971) Check both jails for weapons. Chicago Tribune, 22 September, p. 2.

- Young, A (1996) Imagining Crime. London: Sage. F. 


\section{APPENDIX}

\section{Framing Matrix}

\begin{tabular}{|c|c|c|}
\hline Package & Frame & Position \\
\hline $\begin{array}{l}\text { Order and } \\
\text { Control }\end{array}$ & $\begin{array}{l}\text { The issue is how to provide order, } \\
\text { safety, control, and respect for } \\
\text { authority within a population of rioting } \\
\text { inmates who are holding hostages. }\end{array}$ & $\begin{array}{l}\text { Failure to respect authority, law, and order create } \\
\text { dangerous circumstances for all who live and } \\
\text { work within the institution. }\end{array}$ \\
\hline $\begin{array}{l}\text { Rights of the } \\
\text { Inmates }\end{array}$ & $\begin{array}{l}\text { The issue is how to address the due } \\
\text { process and civil rights of Attica } \\
\text { inmates as afforded under the } \\
\text { Constitution. }\end{array}$ & $\begin{array}{l}\text { Conditions in Attica, before and after the riot, } \\
\text { violate inmates' due process and civil rights. }\end{array}$ \\
\hline $\begin{array}{l}\text { Root Causes of } \\
\text { the Event }\end{array}$ & $\begin{array}{l}\text { The issue is social stratification of } \\
\text { Attica inmates by race and class, } \\
\text { magnified by stratification in broader } \\
\text { American society and inadequacies of } \\
\text { the prison system. }\end{array}$ & $\begin{array}{l}\text { The Attica prisoner population and riot are a } \\
\text { consequence of social conditions, lack of opportunity, } \\
\text { as well as, racial and class stratification inside and } \\
\text { outside the prison walls. }\end{array}$ \\
\hline $\begin{array}{l}\text { Attica the } \\
\text { Community }\end{array}$ & $\begin{array}{l}\text { The issue is individuals from the outside } \\
\text { environment depicting the Attica } \\
\text { prisoner rebellion in a sensationalized } \\
\text { manner inconsistent with actuality. }\end{array}$ & $\begin{array}{l}\text { The Attica prison riot is being managed by a } \\
\text { legitimate department of corrections, staffed by } \\
\text { honest prison guards in a small farming town in } \\
\text { upstate New York. }\end{array}$ \\
\hline $\begin{array}{l}\text { Attica War and } \\
\text { Struggle }\end{array}$ & $\begin{array}{l}\text { The issue is the Attica prisoner as a } \\
\text { political activist raising awareness of } \\
\text { prison conditions and the realities of } \\
\text { prison captivity. }\end{array}$ & $\begin{array}{l}\text { The Attica riot was largely the consequence of } \\
\text { repressive, prison guard brutality, and poor } \\
\text { conditions. The riot is emblematic of an unjust } \\
\text { capitalist society that marginalizes based on race } \\
\text { and class. The riot is a metaphor for war against } \\
\text { an unjust government. }\end{array}$ \\
\hline $\begin{array}{l}\text { The Captive as a } \\
\text { Victim }\end{array}$ & $\begin{array}{l}\text { The issue is Attica inmates as victims } \\
\text { worthy of sympathy and honor for } \\
\text { raising awareness of prison brutality } \\
\text { and cover-ups by government officials. }\end{array}$ & $\begin{array}{l}\text { Rioting inmates were victims of social and legal } \\
\text { conditions at Attica Prison. Inmates are political } \\
\text { heroes, freedom fighters, and revolutionaries for } \\
\text { raising prisoner issues. }\end{array}$ \\
\hline
\end{tabular}

\begin{tabular}{|c|c|c|}
\hline Package & Exemplars & Catchphrases \\
\hline $\begin{array}{c}\text { Order and } \\
\text { Control }\end{array}$ & $\begin{array}{l}\text { Stories, incidents, and data concerning } \\
\text { the chaos instituted by radical prisoners } \\
\text { and inmates leaders orchestrating the } \\
\text { hostage taking and rioting in Attica. }\end{array}$ & $\begin{array}{l}\text { Maximum security; Greater loss of life would have } \\
\text { occurred; Governor had to act; Order must be } \\
\text { restored; Rebelling convicts; Legal police action; Force } \\
\text { necessary to quell disorder; State police sharpshooters } \\
\text { saved many lives. }\end{array}$ \\
\hline $\begin{array}{c}\text { Rights of the } \\
\text { Inmates }\end{array}$ & $\begin{array}{l}\text { Stories, incidents, and data concerning } \\
\text { the violation of prisoner's due process } \\
\text { and civil rights. }\end{array}$ & $\begin{array}{c}\text { Harm to prisoners; legal protection; Fair treatment; } \\
\text { Legal aid for prisoners; Reform and citizen involvement; } \\
\text { Constitutional rights. }\end{array}$ \\
\hline $\begin{array}{c}\text { Root Causes of } \\
\text { the Event }\end{array}$ & $\begin{array}{l}\text { Stories, incidents, and data depicting } \\
\text { racial and class stratification between } \\
\text { inmates and prison guards, outdated } \\
\text { architectural design, racially charged } \\
\text { overtones of the prison system, and need } \\
\text { for prison reform. }\end{array}$ & $\begin{array}{c}\text { Lily-white town; Repression of political rights; } \\
\text { Fixing social conditions; Penal system reform; } \\
\text { Fixing social conditions/societal change; Black and } \\
\text { Puerto Rican inmates }\end{array}$ \\
\hline $\begin{array}{c}\text { Attica the } \\
\text { Community }\end{array}$ & $\begin{array}{l}\text { Stories and incidents presenting the } \\
\text { Attica community, prison guards and } \\
\text { officials, and the government as victims } \\
\text { of the riot and media misrepresentation } \\
\text { of facts. }\end{array}$ & $\begin{array}{l}\text { Negotiating team is comprised of outsiders who } \\
\text { represent norms outside of the mainstream; Convicts } \\
\text { not giving up and jumping at the chance to execute } \\
\text { hostages. }\end{array}$ \\
\hline
\end{tabular}




\begin{tabular}{|c|c|c|}
\hline $\begin{array}{c}\text { Attica War and } \\
\text { Struggle }\end{array}$ & $\begin{array}{l}\text { Stories and incidents representing the } \\
\text { riot as a political movement in reaction } \\
\text { to unjust treatment of prisoners and } \\
\text { changes in the racial makeup of the } \\
\text { prison population. }\end{array}$ & $\begin{array}{l}\text { Attica uprising; Assault on Attica Prison; Horror } \\
\text { of Attica; Criminal mentality of law enforcement } \\
\text { officials; Massacre; Goon squad; Prisoner rebellion; } \\
\text { Storming of the prison; Over } 40 \text { slain; Rebelling } \\
\text { convicts; Uprising; Blood bath; Bloodiest penal } \\
\text { insurrection; Barricades stormed by troopers; } \\
\text { Revolt/bloodiest revolt; Convict massacre; Attack on } \\
\text { press; Freedom of the press. }\end{array}$ \\
\hline $\begin{array}{c}\text { The Captive as } \\
\text { a Victim }\end{array}$ & $\begin{array}{l}\text { Stories, incidents and data chronicling } \\
\text { government cover-ups, sequestering of } \\
\text { prisoners, beatings, brutalization, and } \\
\text { murder of inmates; Stories depicting } \\
\text { violation of human rights, coercion, } \\
\text { retaliation, and unauthorized/unlawful } \\
\text { use of force against Attica prisoners. }\end{array}$ & $\begin{array}{l}\text { Humanitarian reasons; Concentration camp for } \\
\text { blacks; Humanity of inmates holding guards hostage; } \\
\text { Governor Rockefeller could have saved the situation; } \\
\text { Hostages and inmates did not have to die; Prisoners' } \\
\text { side of the story/two sides to the story; Organized } \\
\text { manslaughter; Search for the truth; Cover-up by } \\
\text { insiders; Murdered by the minions of the law; } \\
\text { Dumped from stretchers; Violation of the Geneva } \\
\text { Convention. }\end{array}$ \\
\hline
\end{tabular}

\begin{tabular}{|c|c|c|c|}
\hline Package & Depictions & Roots & Principles \\
\hline $\begin{array}{l}\text { Order and } \\
\text { Control }\end{array}$ & $\begin{array}{l}\text { Attica prisoners are } \\
\text { dangerous and violent. } \\
\text { The state must intercede } \\
\text { to quell the riot through } \\
\text { necessary force. }\end{array}$ & $\begin{array}{l}\text { The root of the problem is the } \\
\text { actions of radical prisoners. } \\
\text { These prisoners need to be dealt } \\
\text { with in a forceful manner to end } \\
\text { their rebellion and limit future } \\
\text { riots. }\end{array}$ & $\begin{array}{l}\text { Respect for authority and control } \\
\text { of violent prisoner actions; } \\
\text { Integrity of the criminal justice } \\
\text { and corrections systems. }\end{array}$ \\
\hline $\begin{array}{l}\text { Rights of the } \\
\text { Accused }\end{array}$ & $\begin{array}{l}\text { Attica prisoners are } \\
\text { reacting to violations } \\
\text { of their rights by a } \\
\text { correctional system. }\end{array}$ & $\begin{array}{l}\text { The root of the problem is } \\
\text { a justice system that does } \\
\text { not provide constitutional } \\
\text { protection to the imprisoned. }\end{array}$ & $\begin{array}{l}\text { Constitutional rights of the } \\
\text { imprisoned should be upheld. }\end{array}$ \\
\hline $\begin{array}{l}\text { Root Causes } \\
\text { of the Event }\end{array}$ & $\begin{array}{l}\text { Attica prisoners as } \\
\text { oppressed minorities } \\
\text { sequestered within cages by } \\
\text { the government }\end{array}$ & $\begin{array}{l}\text { The root of the problem is that } \\
\text { the Attica prison population is } \\
\text { compartmentalized within the } \\
\text { prison setting by race, class and age. }\end{array}$ & $\begin{array}{l}\text { All citizens of the United States, } \\
\text { including prisoners, have a } \\
\text { voice and a stake (albeit, legally } \\
\text { limited) in defining their living } \\
\text { conditions and their community. }\end{array}$ \\
\hline $\begin{array}{l}\text { Attica the } \\
\text { Community }\end{array}$ & $\begin{array}{l}\text { Accounts of prisoners } \\
\text { mutilating bodies and slitting } \\
\text { the throats of hostages } \\
\text { presented as the reality of the } \\
\text { riot by first-hand witnesses } \\
\text { from the Attica event. }\end{array}$ & $\begin{array}{l}\text { The roots of the problem are } \\
\text { media and other outsiders that } \\
\text { are misrepresenting Attica the } \\
\text { prison, Attica the employee, and } \\
\text { Attica the community. }\end{array}$ & $\begin{array}{l}\text { Attica prison officials and guards, } \\
\text { and Attica community members } \\
\text { are victims of violent prisoners } \\
\text { and inaccurate/sensational media } \\
\text { reporting. Attica community } \\
\text { members trust that prison officials/ } \\
\text { guards are doing their jobs. }\end{array}$ \\
\hline $\begin{array}{l}\text { Attica War } \\
\text { and Struggle }\end{array}$ & $\begin{array}{l}\text { Hostages being treated } \\
\text { with respectand care while } \\
\text { inmate leaders negotiated } \\
\text { for equality within the } \\
\text { prison setting }\end{array}$ & $\begin{array}{l}\text { The root of the problem is } \\
\text { government and corrections } \\
\text { systems that are at war with } \\
\text { citizen activists of the United } \\
\text { States. }\end{array}$ & $\begin{array}{l}\text { The Attica prison riot is an } \\
\text { example of an unjust government } \\
\text { approach to citizens. }\end{array}$ \\
\hline $\begin{array}{l}\text { The Captive } \\
\text { as a Victim }\end{array}$ & $\begin{array}{l}\text { Attica prisoners being } \\
\text { victimized at the hands of } \\
\text { brutal government agents. }\end{array}$ & $\begin{array}{l}\text { The root of the problem is a } \\
\text { government victimizing prisoners } \\
\text { and then covering-up such } \\
\text { brutality. }\end{array}$ & $\begin{array}{l}\text { Attica prisoners are victims of } \\
\text { government-sanctioned brutality } \\
\text { and murder. }\end{array}$ \\
\hline
\end{tabular}

